\title{
Development of the Circular Bioeconomy: Drivers and Indicators
}

\author{
Maximilian Kardung ${ }^{1, *} \mathbb{C}^{\mathbb{C}}$, Kutay Cingiz ${ }^{1} \mathbb{1}$, Ortwin Costenoble ${ }^{2}$, Roel Delahaye ${ }^{3}$, Wim Heijman ${ }^{1,4}$,

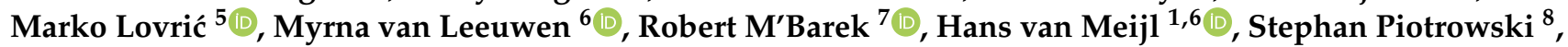 \\ Tévécia Ronzon ${ }^{1,7}{ }^{\circledR}$, Johannes Sauer ${ }^{9}$, David Verhoog ${ }^{6}$, Pieter Johannes Verkerk ${ }^{5}{ }^{\circledR}$, Maria Vrachioli ${ }^{9}{ }^{\circledR}$, \\ Justus H. H. Wesseler ${ }^{1}$ (D) and Benz Xinqi Zhu ${ }^{9}$
}

1 Agricultural Economics and Rural Policy Group, Wageningen University, 6706 KN Wageningen, The Netherlands; kutay.cingiz@wur.nl (K.C.); wim.heijman@wur.nl (W.H.); hans.vanmeij@wur.nl (H.v.M.); tevecia.ronzon@ec.europa.eu (T.R.); justus.wesseler@wur.nl (J.H.H.W.)

2 Royal Netherlands Standardization Institute, 2623 AX Delft, The Netherlands; energy@nen.nl

3 Statistics Netherlands, 2492 JP The Hague, The Netherlands; r.delahaye@cbs.nl

4 Department of Economics, Faculty of Economics and Management, Czech University of Life Sciences, 16500 Prague-Suchdol, Czech Republic

5 European Forest Institute, 80100 Joensuu, Finland; marko.lovric@efi.int (M.L.); hans.verkerk@efi.int (P.J.V.)

6 Wageningen Economic Research, Wageningen University and Research, 2595 BM The Hague, The Netherlands; myrna.vanleeuwen@wur.nl (M.v.L.); david.verhoog@wur.nl (D.V.)

7 Joint Research Centre, European Commission, 41092 Seville, Spain; Robert.M’BAREK@ec.europa.eu

8 nova-Institute $\mathrm{GmbH}, 50354$ Hürth, Germany; stephan.piotrowski@icloud.com

9 TUM School of Life Sciences, Production and Resource Economics, Technical University of Munich, 85354 Freising, Germany; jo.sauer@tum.de (J.S.); maria.vrachioli@tum.de (M.V.); benz.xinqi.zhu@tum.de (B.X.Z.)

* Correspondence: maximilian.kardung@wur.nl

check for updates

Citation: Kardung, M.; Cingiz, K.; Costenoble, O.; Delahaye, R.;

Heijman, W.; Lovrić, M.; van

Leeuwen, M.; M’Barek, R.; van Meijl,

H.; Piotrowski, S.; et al. Development of the Circular Bioeconomy: Drivers and Indicators. Sustainability 2021, 13, 413. https://doi.org/10.3390/ su13010413

Received: 30 November 2020 Accepted: 31 December 2020 Published: 5 January 2021

Publisher's Note: MDPI stays neutral with regard to jurisdictional clai$\mathrm{ms}$ in published maps and institutional affiliations.

Copyright: (C) 2021 by the authors. Licensee MDPI, Basel, Switzerland. This article is an open access article distributed under the terms and conditions of the Creative Commons Attribution (CC BY) license (https:// creativecommons.org/licenses/by/ $4.0 /)$.

\begin{abstract}
The EU's 2018 Bioeconomy Strategy Update and the European Green Deal recently confirmed that the bioeconomy is high on the political agenda in Europe. Here, we propose a conceptual analysis framework for quantifying and analyzing the development of the EU bioeconomy. The bioeconomy has several related concepts (e.g., bio-based economy, green economy, and circular economy) and there are clear synergies between these concepts, especially between the bioeconomy and circular economy concepts. Analyzing the driving factors provides important information for monitoring activities. We first derive the scope of the bioeconomy framework in terms of bioeconomy sectors and products to be involved, the needed geographical coverage and resolution, and time period. Furthermore, we outline a set of indicators linked to the objectives of the EU's bioeconomy strategy. In our framework, measuring developments will, in particular, focus on the bio-based sectors within the bioeconomy as biomass and food production is already monitored. The selected indicators commit to the EU Bioeconomy Strategy objectives and conform with findings from previous studies and stakeholder consultation. Additionally, several new indicators have been suggested and they are related to measuring the impact of changes in supply, demand drivers, resource availability, and policies on sustainability goals.
\end{abstract}

Keywords: bioeconomy; monitoring; indicators

\section{Introduction}

In the last twenty years, policymakers of the European Union (EU) have placed a high priority on a sustainable and circular (bio)economy with the aim to reduce the use of petrochemicals, to mitigate climate change, to reduce the dependency on imports of natural resources, and to promote local economies. This focus on the bioeconomy is evident from a multitude of EU policy initiatives, spearheaded by the European Green Deal, and research programs, including the recent European Bio-Based Industries Joint Undertaking [1,2]. Many bioeconomy strategies on a regional and national level have been developed, most of them in Europe, but also in the United States, South Africa, or Thailand. Those countries are also willing to intensively promote the development 
of their bioeconomies politically, using enabling policy means [3]. Where a designated bioeconomy strategy is missing, the governments have often addressed the topic in related strategies. One example is The Netherlands, where it is linked to the circular economy strategy [4]. The recent EC Bioeconomy Strategy update [5] revalidates the objectives of the 2012 Bioeconomy Strategy, which are now accompanied by three main action areas: bio-based sectors, rural development, and ecological boundaries.

Further, the bioeconomy is seen as an important part of sustainable consumption and production, which gains importance on national, EU, and global levels [6]. Sustainable development combines consumption and production and has three major dimensions: economy, society, and the environment. All three dimensions are addressed in the Sustainable Development Goals (SDGs) global framework, which was launched by the United Nations in 2015 and constituted a landmark in the push for sustainable development [7]. To measure the impacts of the bioeconomy on the three dimensions of sustainable development, a monitoring framework is considered crucial $[8,9]$.

This paper aims to outline the drivers of the circular bioeconomy based on an analysis of important relations within and outside the bioeconomy. Subsequently, we derive the bioeconomy framework's scope using definitions of the bioeconomy and set up an indicator framework to measure and monitor its development along with its social, environmental, and economic impacts. Our study focuses on the EU and EU bioeconomy policies, but where appropriate references to methods and policies beyond the EU are made.

This paper proceeds as follows: Section 2 shows how the bioeconomy works as a system's approach, i.e., which driving forces influence the bioeconomy, what is the impact of the bioeconomy on societal challenges and what are the trade-offs. Section 3 presents various definitions of the bioeconomy, pins it down to related terms, and delimits it using a sectorial view. In Section 4, we review previous efforts on measuring and monitoring the bioeconomy and subsequently present our framework. Section 5 concludes on implications of the previous chapters for our framework.

\section{Driving Forces and Relations within the Bioeconomy}

The development of the bioeconomy is driven by a number of forces and knowing and understanding how they influence the bioeconomy is vital for monitoring and impact assessment [10]. Several studies $[1,11,12]$ identified several major forces steering the development of the bioeconomy. We group these drivers as supply drivers (Sections 2.1-2.3), demand drivers (Section 2.5), resource availability (Section 2.4), and the measures of governments to influence the development of the bioeconomy (Section 2.6).

\subsection{Technology and Innovation}

\subsubsection{Advances in Biological Sciences}

Advances in biological sciences are a major supply driver of the bioeconomy. One of the earliest advances was the fermentation of food products, whose underlying biological processes have been refined over the past thousands of years [1]. Following the first successful recombinant DNA experiments in 1973 by Paul Berg and others, commercial applications of modern biotechnology started in 1982 [13,14].

Today, a wide array of applications of biotechnology and bioengineering, alongside recombinant DNA technologies, are used for improvements in food and feed sectors, biofuels, materials, chemicals, and pharmaceuticals [15,16]. Genetic engineering is likely to play a key role in further developments of non-food applications, but the use of modern biotechnology is not uncontroversial [17]. Policies related to the application of modern biotechnology can have wide-ranging implications that need to be considered for assessing impacts [18-21]. The debate on the use of modern biotechnology has been rekindled by the advent of so-called new plant breeding technologies (NPBTs) for gene editing and related regulatory issues. The regulatory status affects further advances of the CRISPRbased technologies, one of the most important gene-editing tools, as it may disincentivize investments and bring companies to reallocate their research out of the EU [14,22]. In a 
comparison of the worldwide CRISPR patent landscape by Martin-Laffon et al. [23], it is already apparent that Europe is lagging behind the United States and China. Therefore, the development of regulatory measures is an important factor in the further advances in biological sciences.

Technological advances would not have been possible without investments in the bioeconomy. As outlined in the Updated Bioeconomy Strategy "By capitalising on unprecedented advances in life sciences and biotechnologies, as well as innovations merging the physical, digital and biological worlds, the European industrial base can maintain and enhance its global leadership." [5] (p. 6). Investments are directly related to the level of research and development that takes place, which again determines the speed of advances in biological sciences and other technological advances relevant to the bioeconomy. An example is the 100 million euro Circular Bioeconomy Thematic Investment Platform, which the EU should deploy shortly [5]; however, also funding from EC framework programs and public-private partnerships between the European Union and, for example, the Bio-based Industries Consortium. It has formulated a Strategic Innovation and Research Agenda that describes the main technological and innovation challenges to overcome in order to develop sustainable and competitive bio-based industries in Europe. Research, Demonstration, and Deployment have been identified to meet the common EU goals in the bio-based economy.

To understand the effects of innovation and investment efforts in the bioeconomy, monitoring the impact of technological developments in natural sciences on the performance of the bioeconomy in achieving its objectives has been identified as being important [24]. Furthermore, the regulatory environment (e.g., the EU legal framework for the application of genetic modification technology) is of relevance as it has a large influence on technological developments.

\subsubsection{Advances in Information and Communication Technologies}

Another important supply driving force related to innovation is the vast and increasing application of information and communication technologies (ICTs). Watanabe et al. found that in recent years the bioeconomy has taken major steps driven by digital solutions [25]. Smart (digital) farming such as innovative precision farming uses extensively ICTs and is seen key for the development of a sustainable agriculture [26]. The biosciences, and especially genome sequencing and analyses, produce significant amounts of data. Data storage and information analysis tools are vital enablers of bioeconomy innovations such as phenotyping, smart breeding, medical diagnostics, genome discovery and exploration, and therapy development. ICTs also move agriculture, forestry, and fishery management forward. The use of Blockchain technologies, for instance via a distributed database of records structured in encrypted smaller datasets, promise to improve agri-food supply chains [27]. Agri-food supply chains usually involve a high number of intermediaries between producers and consumers. Blockchains can provide a higher level of transparency, efficiency, and guarantee traceability for all kinds of products such as coffee [28], fish [29], or milk [30].

As ICTs improve, many technologies become more affordable, and their use spreads globally, including in developing countries. New developments allow detection of biobased material content in consumer goods supporting labeling as well as tracking and tracing of bio-based materials along the supply chain. Their impacts on the bioeconomy and, therefore, on society, will gain in importance.

\subsubsection{Other Technological Advances}

Technological advances are obviously not limited to biological sciences and ICT only, as advances in other sectors also contribute to the development of the bioeconomy. For example, advances in wood construction technologies may increase the use of wood in construction. The use of wood in multi-storey buildings has long been difficult and often limited to single-family houses or other small-scale buildings. Particularly, the development of engineered wood products, such as cross-laminated timber (CLT), allows for the 
increased use of wood in multi-storey buildings [31,32]. Due to these developments, the markets for engineered wood products-especially CLT -and the use of wood in construction are expected to develop rapidly over the next years to decades [33,34]. Innovations in the chemical industry have the potential to make the use of biomass more cost-efficient than the use of fossil-based raw materials. In the agriculture and food sector, major developments are already taking place. Vertical and indoor farming becomes possible by improvements in the lighting. Indoor aquaculture is making progress for the production of, e.g., seaweed. Meat substitutes make large progress in providing alternatives that are accepted by a majority of the population and are not a niche product anymore. A similar development can be expected with cultured meat, produced by in vitro cultivation of animal cells.

Altogether, these technological developments are relevant for the bioeconomy and need to be monitored as well as investments in the chemical and wood-based industries. Furthermore, new bio-based materials and products have to be integrated into the standardized classification system and data collecting system.

\subsection{Market Organization}

\subsubsection{Advances in Horizontal and Vertical Integration}

Another supply driver is horizontal and vertical integration of bioeconomy supply chains that can influence the supply and demand on bioeconomy markets and impact the sustainability goals. Therefore, looking at the agricultural sector only and not considering the increase in up- and down-stream linkages with other sectors through different forms of contractual arrangements may create biases in policy analysis. Horizontal integration refers to the acquisition of a business operating at the same level of the value chain in a similar or different industry [35]. Through mergers and acquisitions or voluntary collaboration at the farm level, horizontal integration can change the market power of agents with economic and distributional effects along the value chain. Vertical integration refers to the process where different parts of the supply chain (e.g., growing raw materials, manufacturing, transporting, marketing, and/or retailing) are arranged for by a single company. It can be seen as a supply-side response to differentiate products and to reduce the potential decrease in producer rents that might result from an increase in product supply. Further integration of the value chain is also achieved by close partnerships between different companies, whereby an important enabling factor is advances in ICTs.

New bioeconomy value chains have emerged based on the increasing use of natural and renewable resources in non-food applications. A central link for these new value chains are bio-refineries, which have been defined as "a facility (or network of facilities) that integrates biomass conversion processes and equipment to produce transportation biofuels, power, and chemicals from biomass" [36]. In the EU, about 800 biorefineries are running at a different level of maturity (i.e., commercial, demo, pilot, and R\&D). However, this number does not include biogas plants, where in Germany alone there are around 12,000 [37]. The highest geographical concentration of biorefineries is in Northwestern Europe and agricultural resources are the most used feedstock [38]. However, the type of inputs and outputs of a biorefinery can vary widely. For examples, in a Kraft pulp mill biorefinery, a broad range of by-products, such as tall oil, turpentine, bioelectricity, product gas, sulphuric acid, and biogas can be produced from woody raw materials, and in a sugar or starch biorefinery, the main primary products are fermentable sugar and animal feed. The bio-refinery concept is an important part of the value chain of many bio-based products and has the advantage of operating at a much lower temperature, allowing for smaller units to be built in comparison to fossil fuel-based refineries [39]. Nevertheless, the conversion of biomass can result in trade-offs that might be intensified by national and international bioeconomy policies [40]. 


\subsubsection{Globalization}

A further important driving force that influences the markets is globalization, which can be understood as "a process of interaction and integration among the people, companies, and governments of different nations, a process driven by international trade and investment and aided by information technology. This process has effects on the environment, on culture, on political systems, on economic development and prosperity, and on human physical well-being in societies around the world" [41]. Globalization goes beyond the increase in international trade and vertical and horizontal integration. This process contributes to the harmonization of value chains and consumer attitudes around the world. Globalization also affects the geographic location of production and consumption of goods. For example, intensively managed forest plantations in the southern hemisphere are replacing boreal and temperate forests as a source of raw material [33]. Furthermore, the consumption of packaging paper and paperboard is shifting from North America and Western Europe to emerging countries such as China, and these shifts are linked to changes in the location where goods are manufactured [42].

The pervasive forces of digitization and globalization of the socioeconomic system change the framework condition of the bioeconomy. Standards for biorefineries and bio-based products can be expected to be increasingly harmonized and foster positive externalities by reducing approval costs and length and trade disruptions caused by asynchronicity in product approval [43]. Examples are related to the labeling of food, feed, and other bio-based products [21]. This implies trade in products and innovations related to the bioeconomy as well as the regulatory environment at the international level needs to be monitored.

\subsection{Increase in Importance of Climate Change and Pressure on Ecosystems}

Climate change is a particularly complex driving force in the context of the production of biomass for the bioeconomy. On the one hand, it is a major challenge for the agricultural and forestry sectors because a change in climatic conditions as well as more extreme weather events will affect forest and crop growth and wood production [44]. Climate change also increases uncertainty in these sectors and can potentially cause market disruptions [45]. The development of the bioeconomy is considered to reduce emissions and to mitigate climate change, as the use of biological resources, such as wood, manure, food waste, and algae, for producing materials and energy is generally considered to reduce emissions compared to fossil-based, emission-intensive products. Furthermore, the bioeconomy could offer an opportunity to develop new value chains, which could attract private and public investments into improved management practices that could increase the resilience of forests to climate change [46]. The use of new breeding technologies provides tools to develop crops that are suitable for a wide range of micro-agroclimatic conditions much faster and thereby can respond to climate change more effectively. Bio-based products typically have much smaller carbon dioxide $\left(\mathrm{CO}_{2}\right)$ footprints compared to functionally-equivalent products made from fossil-based or fossil-intensive materials [47,48]. However, bio-based products may have greater water, eutrophication, and land-use footprints [49] and biobased products may not always be more environmentally friendly or more sustainable than fossil-based products.

\subsection{Resource Availability}

A variety of resources are needed to fuel the economy such as land, water, air, or skilled labor. The most important resource for the bioeconomy is biomass, either domestically produced or imported. Besides the quantity, also the type and quality of available biomass are important. Biomass can originate from agriculture, forestry, marine environment, and waste. The biomass is then used as food or feed, but also to produce bioenergy and biobased products. Different uses require different types of biomass. The majority of experts consider the competition of biomass for food and non-food use an important conflict that needs to be addressed by bioeconomy strategies [50]. A large future potential lies in 
waste biomass, especially agricultural residues and food waste. Monitoring the flow of biological and other materials within the economy provides information about the potential availability and current stream of biomass [51]. Such monitoring can be used to measure resource efficiency, resource dependency, production of solid waste and recycling, pressure on the environment, and footprints [52,53].

\subsection{Demographics, Economic Development, and Consumer Preferences}

The strong world population growth is another important determinant on the demandside. Naturally, a growing population leads to an increase in demand for all kinds of products. For example, the pressure on cropland use further expands due to a higher demand for non-food biomass that is induced by the evolution towards a bioeconomy. The increasing competition for cropland happens at the expense of shrinking grasslands, savannahs, and forests, primarily in tropical countries [54], and potentially leads to biodiversity losses and greenhouse gas emissions. Next, a shifting consumer demand based on the awareness of the need to ensure sustainable production and consumption is expected to be a major factor driving future markets in the EU. For example, rising awareness on environmental issues like climate change and plastic pollution could lead to a change in consumer preferences, resulting in higher demand for bio-based products [55]. Previous studies have shown that consumers value the health and environmental attributes of novel food products [56] and that fully bio-based products result in greater purchase intentions [57].

Other consumer studies, however, have shown great confusion of consumers regarding the term "bio-based products" and many misunderstandings regarding, e.g., biodegradability or organic content [58]. Product labels have been introduced to respond to consumer preferences and they enable the monitoring of expected shifts in demand. So far, this paper has demonstrated that several driving forces affect the developments of the bioeconomy and its impacts on the economy, society, and the environment. The following two sections will discuss the resources that act as an important constraint and the policy measures that can be used to steer the development.

\subsection{Policies, Strategies, and Legislation}

\subsubsection{Global, EU and National Policies}

Agricultural, fisheries, and forestry policies steer the primary production sector, which is influential to the whole bioeconomy. Furthermore, policies on both, renewable energy and energy from fossil fuels, are driving the bioeconomy. Renewable energy targets and subsidies generally result in an increase in bioenergy production. The focus on bioenergy in the policy landscape could also affect other parts of the bioeconomy, lead to distortions within the bioeconomy (such as over-cultivation of energy crops), and hinder environmental benefits and cascading use of biomass [59]. Bioeconomy strategies take a big role as they outline the visions and intentions of countries and regions $[40,60]$. The market mechanisms of the bioeconomy are of high complexity and policy measures targeted toward single effects involve trade-offs, leakage, and rebound effects [61]. This implies that also policies not directly targeted at the bioeconomy can have a considerable effect. For example, tax policies on fossil fuel can lead to substitution effects between fossil fuel-based products and bio-based products and are a key determinant of bioeconomy development [62].

Moreover, policies related to the circular economy are influential for the bioeconomy because of the synergies between both approaches (see Section 3.2 for details). The European Commission's 2015 CE action plan addressed the transformation of EU MS into a circular economy focusing on the supply-side for production, consumption, secondary raw materials, innovation and investment, and monitoring [63]. The 2020 EU Circular Economy action plan, which was published as part of the Communication on a European Green Deal, followed up with more focus on the consumer-side and the aim to establish a coherent product policy framework and promote sustainable products, services, and business models [64]. 


\subsubsection{Regional Policies}

Bio-based products and industries offer new opportunities for European rural and coastal regions due to their local biomass resources such as agriculture, marine ecosystems, and forests, which can be supplemented by municipal waste streams. Investments in new bio-based industries can be best planned at the regional level where efforts can be targeted and based upon regional attributes, strengths, and opportunities. At the regional level, the bioeconomy could endorse a positive impact in terms of job creation and building a circular economy. The regional dimension of the bioeconomy is especially supported by EU initiatives like the EU Bioeconomy Strategy, the EU Cohesion Policy, and the introduction of Regional Innovation Strategies for Smart Specialisation (RIS3). With RIS3, regions are challenged to make strategic choices for their own socioeconomic development based on their regional characteristics and assets. The EU supports this trajectory by offering H2020 funding for exploring innovations and the European Regional Development Fund for piloting and implementing regional initiatives.

Although many European regions have expressed ambitions to valorize agricultural, forest, marine, or urban biomass and waste into new bio-based products (i.e., 100-170 regions have a bioeconomy related focus in their RIS3, depending on the selection criterion), only a few regions have successfully been through the development path and succeeded in establishing bio-based industries to date (e.g., Hauts-de-France and Grand Est regions in France as part of IAR cluster in France, Central Finland, Biobased Delta in the Netherlands). Most of these success cases exist in regions with established chemical, energy, and paper and pulp industries, which provided the foundation for building new bio-based industries and clusters to attract investors and to bring sustainable bio-based products to the market [65].

\subsubsection{Legislation}

Legislation can act as a strong policy tool to steer the bioeconomy. There are a large number of legislative acts that are relevant for the bioeconomy in the EU, but no specific EU bioeconomy legislation exists [66]. The European Agricultural Guarantee Fund (EAGF) provides direct payments to farmers, based on the type of biomass they produce and compliance with basic standards concerning the environment (e.g., food safety and animal welfare). Furthermore, green direct payments can be received for practices that benefit the environment and climate. The European Agricultural Fund for Rural Development (EAFRD) finances the so-called agri-environment-climate measures, which affect the availability, prices, and price stability of biomass and the environmental impact of agricultural commodities. The Common Fisheries Policy regulates fisheries management, international policy, market organization, and the European Maritime and Fisheries Fund has high relevance for biomass from the maritime environment. The EU food and feed safety legislation is a very comprehensive regulation that the food industry has to comply with [66]. The Renewable energy directive sets targets for renewable energy shares, which promotes the uptake of bioenergy and biofuels. The Waste Framework Directive and many further legal acts regulate the management of waste in the EU. These regulations have a large impact on the development of the bioeconomy because they steer the handling of bio-waste streams.

\subsection{Relations within the Bioeconomy}

Figure 1 summarizes the issues discussed in the previous sections of our conceptual framework. This should be seen as a dynamic and not as a static process. The DriversImpact-Results (DIR) framework has been adapted from the SAT-BBE project [12]. On the left side are the supply and demand drivers, which determine the development of the bioeconomy. Policies, strategies, and legislation on the top constitute the measures of governments to influence this development. At the bottom, we can see the different resource availabilities for biomass production, like land, water, and labor, which influence the biomass market in the center. In the center of the framework are the different supplies and uses of biomass, which are endogenously determined through the aforementioned 
three boxes of driver types. Furthermore, waste/by-products, whose usage is the key to a sustainable and circular bioeconomy, have been taken into account. In combination, the drivers, policies, and resources have an impact on the demand and supply of the bioeconomy which in its turn determines to what extent it will contribute to achieving sustainable and policy targets of the objectives (right-hand side).

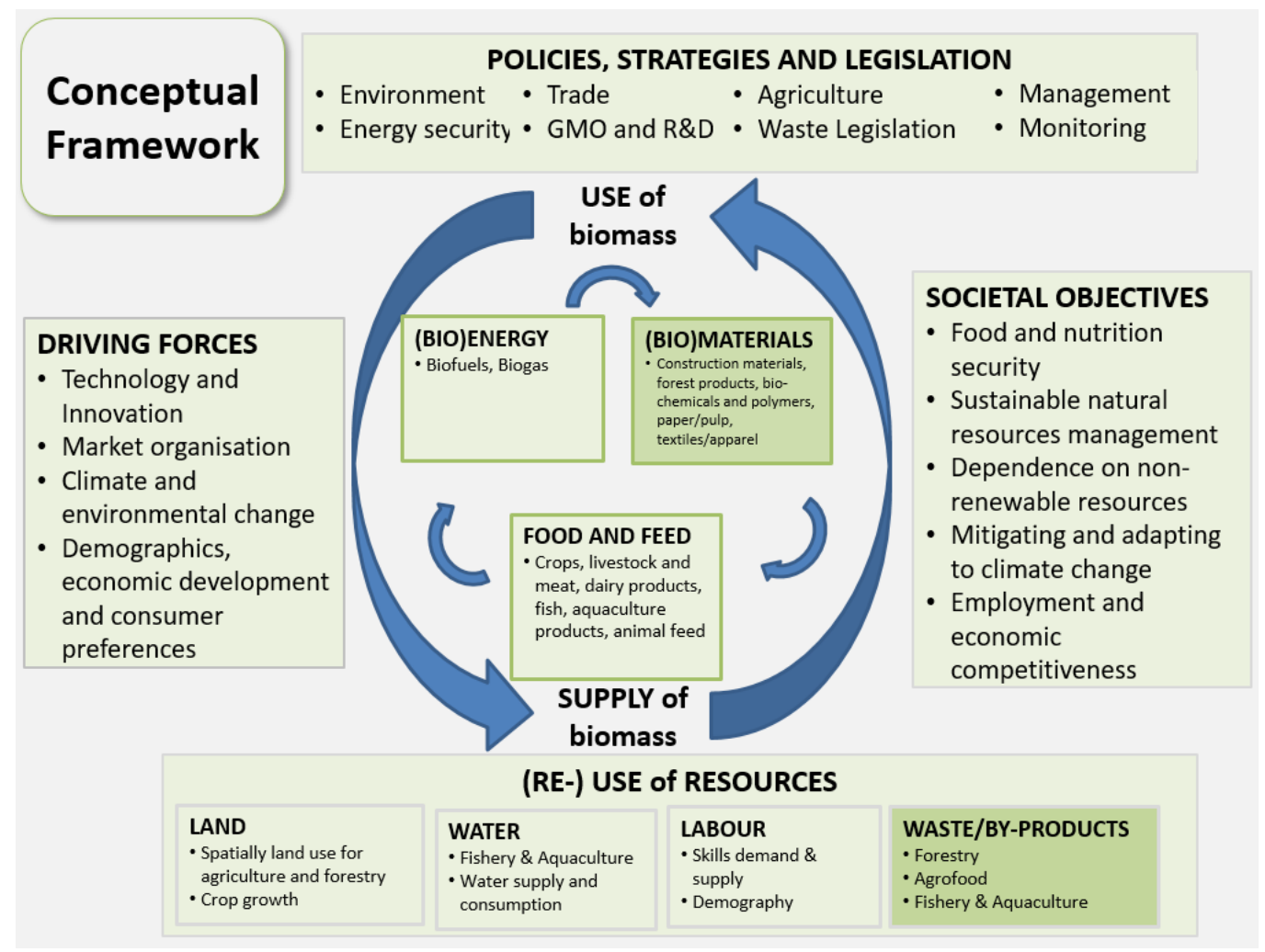

Figure 1. Overview of the relations within the bioeconomy. Source: Adapted from SAT-BBE [12].

To make the impacts on the objectives measurable, they must be transformed into criteria or targets. For example, the objective 'mitigating climate change' could be reflected in the criteria 'reduce greenhouse gas (GHG) by $40 \%$ by 2030 as compared to 1990 '. Therefore, meaningful indicators must be assigned that can measure the development and impacts of the bioeconomy in relation to the criteria and policy targets. For example, the indicator $\%$ $\mathrm{CO}_{2}$ in bio-based and fossil-based sectors' could be applied to measure the impact on the target 'reduce GHG with $40 \%$ '.

Insights into the impacts on the targets of the objectives will likely trigger responses from policymakers (i.e., by reforming the policy or introducing new measures) or from stakeholders in the private sector (i.e., by investing in techniques or changing their management). In their turn, the responses might influence the drivers behind the development of the bioeconomy again, such as consumer preferences, economic development, innovation, and technological change. Policy targets are thus quite closely connected to drivers as they are answers that anticipate the affected sustainable objectives caused by the status of drivers and resource availabilities so far. In their turn, adapted policy targets in conjunction with the drivers will again influence the sustainable objectives behind the bioeconomy. This iterative process will continue until the environmental, economic, and social sustainable objectives will be sufficiently satisfied.

This process shows that the bioeconomy is a complex system and therefore its monitoring requires a comprehensive systems analysis. Both dynamics within the bioeconomy and interactions and pressures from the outside influence the development. These factors include the changes in existing sectors and products, changes in interactions between sectors, and the creation of new bio-based products. It is not possible to foresee all new de- 
velopments, but a look at the driving forces of these developments provides an insight into what parts of the bioeconomy deserve closer attention. A priority is to be able to capture the level of sustainability and circularity of the bioeconomy. Furthermore, the monitoring has to be spatially explicit to analyze the development of the local bioeconomy. As the advances in technology constitute an important driving force of the bioeconomy, monitoring must include private and public efforts to advance these technological developments.

\section{Defining and Delimiting the Bioeconomy}

\subsection{Definition}

The bioeconomy has an inter-sectoral, (inter)national, and transdisciplinary nature, which is reflected in varying definitions and delimitations. The way in which the term is defined and in which its activities are delimited depends on the stakeholders: scientists, policymakers, NGOs, or the private sector. Bugge et al. identified three visions of the bioeconomy, that is a biotechnology vision, a bio-resource vision, and a bio-ecology vision, which are associated with different actors and reflect their priorities in the bioeconomy [67]. Furthermore, the bioeconomy is considered as being of pervasive nature, not only a sector but more and more integrated into day to day life, similar to digitalization [1]. This presents a challenge for monitoring and measuring the bioeconomy, for which a clear scope is necessary.

Within Europe, one of the most used definitions is the one defined by the European Commission [5] (p. 4), who define that "The bioeconomy covers all sectors and systems that rely on biological resources (animals, plants, micro-organisms and derived biomass, including organic waste), their functions and principles. It includes and interlinks: land and marine ecosystems and the services they provide; all primary production sectors that use and produce biological resources (agriculture, forestry, fisheries, and aquaculture); and all economic and industrial sectors that use biological resources and processes to produce food, feed, bio-based products, energy, and services".

The Commission's definition of the bioeconomy in its 2018 Bioeconomy Strategy Update expands on the Commission's 2012 definition by including a wider array of products, sectors, and value chains. Furthermore, the strategy stresses that "to be successful, the European bioeconomy needs to have sustainability and circularity at its heart," thereby emphasizing sustainability and circularity.

The Global Bioeconomy Summit provides another frequently used definition. The summit brings together ministers and government representatives from Asia, Africa, Europe, South and North America, international policy experts from the United Nations, the Organization for Economic Co-operation and Development and the European Commission, as well as high-level representatives from science and industry. The 2018 Global Bioeconomy Summit defined the bioeconomy as " $[$. . . ] the production, utilization, and conservation of biological resources, including related knowledge, science, technology, and innovation, to provide information, products, processes, and services across all economic sectors aiming toward a sustainable economy" [68] (p. 2).

The European Bioeconomy Alliance, a cross-sector overarching alliance of various bioeconomy industries associations (e.g., The European Vegetable Oil and Protein Meal Industry), has a comprehensive definition of the bioeconomy:

"The bioeconomy comprises the production of renewable biological resources and their conversion into food, feed, bio-based products, and bioenergy via innovative, efficient technologies. In this regard, it is the biological motor of a future circular economy, which is based on optimal use of resources and the production of primary raw materials from renewably sourced feedstock" [69] (p. 1)

This definition includes the concept of the circular economy and emphasizes the relationship between the circular economy and the bioeconomy in that the progress in the bioeconomy is stimulating the transition to a circular economy.

Another perspective comes from organizations representing different sectors within the bioeconomy. They emphasize the role of their sectors and how those sectors can con- 
tribute to the overall objectives of the bioeconomy on the one hand, and how their sectors can benefit from the bioeconomy on the other hand. An example is the Confederation of European Forest Owners:

"Sustainable, multifunctional forest management and the forest-based sector play a key role in achieving Sustainable Development Goals, for example, by providing climate action, sustaining life on land, delivering work and economic growth, enhancing responsible production and consumption, boosting industry innovation and infrastructure, creating sustainable cities and communities, enhancing good health and well-being, and providing clean energy. The bioeconomy is a key concept to boost the potential of the forest sector to deliver solutions to these multiple challenges." [70] (p. 2)

In this definition, the Sustainable Development Goals are the primary objective and the bioeconomy is considered a viable solution for their achievement.

In summary, this non-exhaustive selection of definitions provides additional information to and confirm the EC's perspective on the scope of the bioeconomy. The 2018 Global Bioeconomy Summit specifically mentions the conservation of biological resources to be included in the bioeconomy. The European Bioeconomy Alliance emphasizes the importance of the synergies between the bioeconomy and the Circular Economy. Moreover, the Confederation of European Forest Owners highlights the potential of the bioeconomy to contribute to the Sustainable Development Goals. Hence, a wide range of stakeholders supports the EU bioeconomy not only within the EU but also beyond.

\subsection{Bioeconomy, Bio-Based Economy, Green Economy, and Circular Economy}

In addition to the term 'bioeconomy', there exist several related terms, such as 'biobased economy', 'green economy', and 'circular economy'. Figure 2 shows the relation and overlap between the terms. The green economy is generally considered as being an umbrella concept [71] and is understood to "result in improved human well-being and social equity, while significantly reducing environmental risks and ecological scarcities. In its simplest expression, a green economy can be thought of as one which is a low carbon, resource-efficient and socially inclusive" [72] (p. 1). The bioeconomy is generally considered to be part of the green economy (Figure 2). Generally, the bioeconomy is often more related to promoting global economic growth and technological development than purely focusing on limits to growth as a consequence of resource scarcity, depletion, and expected population growth [73].

The concept of the bioeconomy has early-on been linked with the concepts of the biobased and the circular economy. The bio-based economy is seen as part of the bioeconomy and relates to the conversion of biological resources into products and materials. This is also referred to as bio-based production. In some definitions of the bio-based economy, an emphasis is put on innovative bio-based products such as biopolymers and bioplastics [74] while in others, traditional bio-based products such as bio-based textiles, wood products, pulp, and paper are explicitly included as well [75]. Figure 2 summarizes the different concepts being used and uses the latter definition of the bio-based economy and additionally includes the food and feed sector in the bio-based economy. The production of food and feed usually involves the processing of agricultural goods and, therefore, fits into the bio-based economy.

The circular economy, which shares the rise in popularity and can work complementary to the bioeconomy [76], can be described as an economy in which products and materials used show a high degree of recycling and reduction, contrary to a linear economic model that builds on a 'take-make-consume-throw away' pattern [77]. Substitution of non-renewables with sustainably produced biomass is also an important part of the circular economy. The concept of circularity is not new and has been the foundation for economy-wide modeling dating back at least to the works of François Quesnay and the Physiocratic school of the 18th century in France. The Ellen MacArthur Foundation, a strong supporter of the circular economy concept, defines it as "an industrial economy that is restorative or regenerative 
by intention and design" [78] (p. 14). Similarly, the European Commission defines the circular economy as an economy "where the value of products, materials, and resources is maintained in the economy for as long as possible, and the generation of waste minimized, [it] is an essential contribution to the EU's efforts to develop a sustainable, low carbon, resource-efficient and competitive economy" [63] (p. 2).

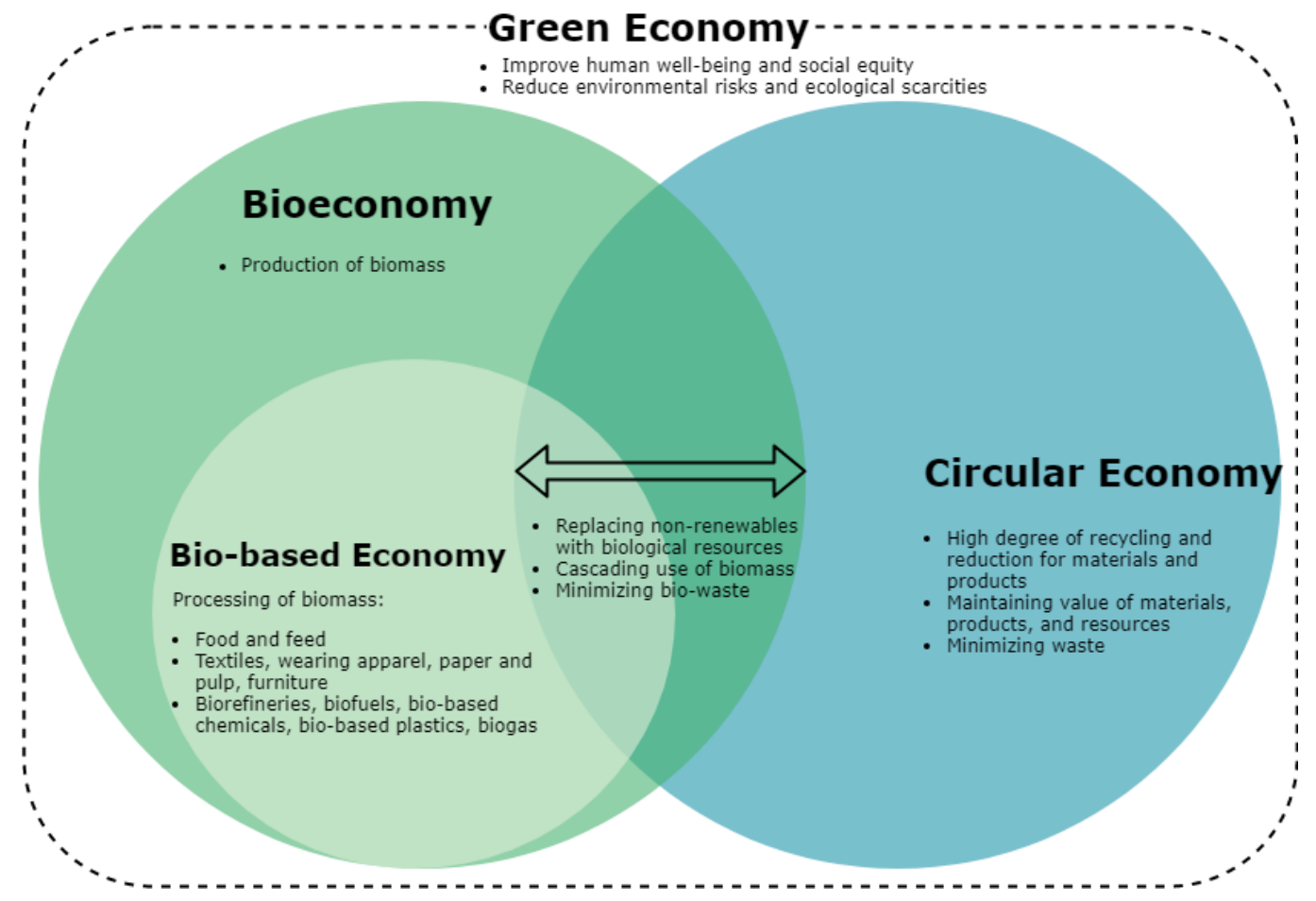

Figure 2. Relations between bioeconomy, bio-based economy, green economy, and circular economy.

The synergies between the bioeconomy and circular economy concepts are significant. Several European industry associations such as CEPI (Confederation of European Paper Industries) and EuropaBio (The European Association for Bioindustries) use and support the concept of a 'circular bioeconomy' and promote greater integration of both concepts instead of developing both in parallel [70,79] (EuropaBio, 2017; CEPI, 2017). Recently, the term circular bioeconomy has been introduced by the EC, among others, to intertwine the bioeconomy and circular economy concepts and emphasize the use of a circular approach to the bioeconomy, but also to show limitations of the overlap $[75,80,81]$.

\subsection{Sectors in Bioeconomy and Bio-Based Economy}

To monitor the bioeconomy and considering the broad definition of the bioeconomy by the European Commission, there is a need to define which sectors make up the bioeconomy $[82,83]$. Bioeconomy-related activities can be broadly classified as (i) Natural-resource based activities that directly exploit a biological resource (e.g., the primary sectors agriculture, fishery, and forestry) and provide biomass for further processing; (ii) Conventional manufacturing activities that further process biomass (e.g., food or wood processing sectors); and (iii) Novel activities that further process the biomass and/or biomass residues (bioenergy or bio-based chemical sectors). The Statistical Classification of Economic Activities in the European Community (NACE) provides a useful starting point for defining which and to what extent economic activities belong to the bioeconomy. Its divisions A01A03 (i.e., agriculture, forestry, and fishery) are unambiguous as they constitute entire sectors and cornerstones of the bioeconomy. Apart from the primary sectors in Section A, the main part of the bioeconomy can be located in Section C-Manufacturing. Divisions C10 (food products), C11 (beverages), C12 (tobacco products), C16 (wood and wood products), and C17 (paper and paper products) are conventional bioeconomy sectors that further process 
biomass and can be attributed to the bioeconomy. C13 (textiles), C14 (wearing apparel), C15 (leather and related products), C19 (coke and refined petroleum products), and C31 (furniture) are traditional sectors that to some extent use bio-based input. In the case of C19, the sector includes the blending of biofuels with petroleum products. Like in most other studies, they are part of the bioeconomy, but only for their share of bio-based production. C20 (chemical products), C21 (pharmaceutical products), and C22 (rubber and plastic products) are sectors, which include novel activities that further process biomass, often as a substitute for fossil-based raw material. This substitution is an important objective of the bioeconomy and, therefore, these potential bio-based sectors are included in the list. In order to measure the development of new, innovative industries that make novel use of biomass, biorefineries and cascading use of biomass are two essential concepts that should be captured.

Apart from the manufacturing sectors, several additional service-related sectors partly use processed biological resources. These are D35 (electricity, gas, steam and air conditioning supply), F41 (construction), F42 (civil engineering), G46 (wholesale trade), G47 (retail trade), I55 (accommodation), and I56 (food and beverage service activities). For service sectors, it is a challenge to determine which share of the use of biological resources (and therefore part of the bioeconomy) can be assigned to them. However, the importance of the service sector for GDP and employment in the EU has become so substantial that a large proportion of the bioeconomy would be omitted from the analysis if it would be ignored. Efken et al. use estimates from different market research companies to calculate the share of biobased related activities in total turnover for G46 (wholesale trade), G47 (retail trade), I55 (accommodation), and I56 (food and beverage service activities) for Germany [84]. However, for the case of restaurants, they do not find any reliable estimates on the share of turnover related to biological resources and, therefore, consider restaurants completely as part of the bioeconomy.

Table 1 summarizes the sectors that we consider to belong to the bioeconomy according to previous efforts $[61,84-89]$. For example, Ronzon et al. in their report use 16 sectors, and the major indicators applied include turnover, value-added, and jobs [86]. Statistics and methods measuring the contribution of the bioeconomy to reaching the global societal objectives are relatively well equipped and developed for its traditional sectors and products like food, feed, pulp and paper, and bioenergy chains [88], but there are gaps for the innovative biobased sectors. For example, according to Ronzon and $\mathrm{M}^{\prime} \mathrm{Barek}$, the EU-28 bioeconomy was responsible for 18 million full-time jobs, generated $€ 2.3$ trillion of turnover, and contributed to a value addition of $€ 620$ billion in 2015 [86]. 
Table 1. Sectors of the bioeconomy and the bio-based economy.

\begin{tabular}{|c|c|c|c|c|c|c|c|c|}
\hline & NACE & $\begin{array}{l}\text { Fumagalli and } \\
\text { Trenti }[87]\end{array}$ & $\begin{array}{l}\text { SAT-BBE } \\
\quad[60]\end{array}$ & $\begin{array}{c}\text { Efken et al. } \\
\text { [84] }\end{array}$ & $\begin{array}{c}\text { Ronzon et al. } \\
{[86]}\end{array}$ & $\begin{array}{c}\text { Piotrowski et al. } \\
\text { [89] }\end{array}$ & $\begin{array}{c}\text { Ronzon et al. } \\
{[85]}\end{array}$ & $\begin{array}{c}\text { Our } \\
\text { FRAMEWORK }\end{array}$ \\
\hline A01 & $\begin{array}{l}\text { Crop and animal production, hunting and } \\
\text { related service activities }\end{array}$ & $\checkmark$ & $\checkmark$ & $\checkmark$ & $\checkmark$ & $\checkmark$ & $\checkmark$ & $\checkmark$ \\
\hline A02 & Forestry and logging & $\checkmark$ & $\checkmark$ & $\checkmark$ & $\checkmark$ & $\checkmark$ & $\checkmark$ & $\checkmark$ \\
\hline A03 & Fishing and aquaculture & $\checkmark$ & $\checkmark$ & $\checkmark$ & $\checkmark$ & $\checkmark$ & $\checkmark$ & $\checkmark$ \\
\hline $\mathrm{C} 10$ & Manufacture of food & $\checkmark$ & $\checkmark$ & $\checkmark$ & $\checkmark$ & $\checkmark$ & $\checkmark$ & $\checkmark \checkmark$ \\
\hline $\mathrm{C} 12$ & Manufacture of tobacco & $\checkmark$ & $\checkmark$ & $\checkmark$ & $\checkmark$ & $\checkmark$ & $\checkmark$ & $\checkmark \checkmark$ \\
\hline $\mathrm{C} 13$ & Manufacture of textiles & $X$ & $\checkmark$ & $\checkmark$ & $\checkmark$ & $\checkmark$ & $\checkmark$ & $\checkmark \checkmark$ \\
\hline C14 & Manufacture of wearing apparel & $x$ & $\checkmark$ & $\checkmark$ & $\checkmark$ & $\checkmark$ & $\checkmark$ & $\checkmark \checkmark$ \\
\hline C15 & Manufacture of leather and related products & $x$ & $\checkmark$ & $\checkmark$ & $\checkmark$ & $\checkmark$ & $\checkmark$ & $\checkmark \checkmark$ \\
\hline $\mathrm{C} 16$ & $\begin{array}{l}\text { Manufacture of wood and products of wood } \\
\text { and cork, except furniture; manufacture of } \\
\text { articles of straw and plaiting materials }\end{array}$ & $\checkmark$ & $\checkmark$ & $\checkmark$ & $\checkmark$ & $\checkmark$ & $\checkmark$ & $\checkmark \checkmark$ \\
\hline C19 & $\begin{array}{l}\text { Manufacture of coke and refined petroleum } \\
\text { products }\end{array}$ & $x$ & $\checkmark$ & $x$ & $x$ & $\mathrm{X}$ & $x$ & $\checkmark \checkmark$ \\
\hline $\mathrm{C} 20$ & $\begin{array}{l}\text { Manufacture of chemicals and chemical } \\
\text { products }\end{array}$ & $\checkmark$ & $\checkmark$ & $\checkmark$ & $\checkmark$ & $\checkmark$ & $\checkmark$ & $\checkmark \checkmark$ \\
\hline $\mathrm{C} 21$ & $\begin{array}{l}\text { Manufacture of basic pharmaceutical } \\
\text { products and pharmaceutical preparations }\end{array}$ & $X$ & $x$ & $\checkmark$ & $\checkmark$ & $\checkmark$ & $\checkmark$ & $\checkmark \checkmark$ \\
\hline $\mathrm{C} 22$ & Manufacture of rubber and plastic products & $x$ & $\checkmark$ & $x$ & $\checkmark$ & $\checkmark$ & $\checkmark$ & $\checkmark \checkmark$ \\
\hline $\mathrm{C} 31$ & Manufacture of furniture & $X$ & $\checkmark$ & $X$ & $\checkmark$ & $\checkmark$ & $\checkmark$ & $\checkmark \checkmark$ \\
\hline D35 & $\begin{array}{l}\text { Electricity, gas, steam, and air conditioning } \\
\text { supply }\end{array}$ & $X$ & $\checkmark$ & $x$ & $\checkmark$ & $\checkmark$ & $x$ & $\checkmark \checkmark$ \\
\hline D3511 & Production of electricity & $x$ & $\checkmark$ & $x$ & $x$ & $x$ & $\checkmark$ & $\checkmark \checkmark$ \\
\hline E36 & Water collection, treatment, and supply & $x$ & $x$ & $x$ & $x$ & $x$ & $x$ & $\checkmark$ \\
\hline E37 & Sewerage & $X$ & $x$ & $x$ & $x$ & $X$ & $x$ & $\checkmark$ \\
\hline
\end{tabular}


Table 1. Cont.

\begin{tabular}{|c|c|c|c|c|c|c|c|c|}
\hline & NACE & $\begin{array}{l}\text { Fumagalli and } \\
\text { Trenti }[87]\end{array}$ & $\begin{array}{l}\text { SAT-BBE } \\
{[60]}\end{array}$ & $\begin{array}{c}\text { Efken et al. } \\
\text { [84] }\end{array}$ & $\begin{array}{l}\text { Ronzon et al. } \\
{[86]}\end{array}$ & $\begin{array}{c}\text { Piotrowski et al. } \\
\text { [89] }\end{array}$ & $\begin{array}{l}\text { Ronzon et al. } \\
{[85]}\end{array}$ & $\begin{array}{c}\text { Our } \\
\text { FRAMEWORK }\end{array}$ \\
\hline E38 & $\begin{array}{l}\text { Waste collection, treatment, and disposal } \\
\text { activities; materials recovery }\end{array}$ & $x$ & $x$ & $x$ & $x$ & $x$ & $x$ & $\checkmark$ \\
\hline E39 & $\begin{array}{l}\text { Remediation activities and other waste } \\
\text { management services }\end{array}$ & $x$ & $x$ & $x$ & $x$ & $x$ & $x$ & $\checkmark$ \\
\hline F41 & Construction of buildings & $x$ & $\checkmark$ & $x$ & $x$ & $X$ & $x$ & $\checkmark$ \\
\hline F42 & Civil engineering & $X$ & $\checkmark$ & $x$ & $X$ & $x$ & $x$ & $\checkmark$ \\
\hline G46 & $\begin{array}{l}\text { Wholesale trade, except for motor vehicles } \\
\text { and motorcycles }\end{array}$ & $x$ & $x$ & $\checkmark$ & $x$ & $x$ & $x$ & $\checkmark$ \\
\hline G47 & $\begin{array}{l}\text { Retail trade, except for motor vehicles and } \\
\text { motorcycles }\end{array}$ & $X$ & $x$ & $\checkmark$ & $x$ & $x$ & $x$ & $\checkmark$ \\
\hline $\mathbf{H}$ & Transportation and storage & $x$ & $x$ & $x$ & $x$ & $x$ & $x$ & $\checkmark$ \\
\hline I55 & Accommodation & $x$ & $x$ & $\checkmark$ & $x$ & $x$ & $x$ & $\checkmark$ \\
\hline I56 & Food and beverage service activities & $x$ & $x$ & $\checkmark$ & $x$ & $x$ & $x$ & $\checkmark$ \\
\hline R9104 & $\begin{array}{c}\text { Botanical and zoological gardens and nature } \\
\text { reserves activities }\end{array}$ & $x$ & $x$ & $\mathrm{X}$ & $x$ & $x$ & $x$ & $\checkmark$ \\
\hline
\end{tabular}

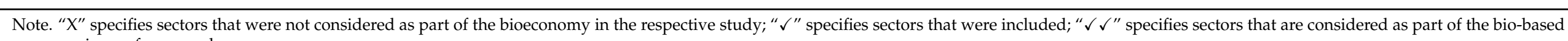
economy in our framework. 


\section{Monitoring and Measuring the Bioeconomy}

\subsection{Stocktaking of Monitoring Systems}

There are efforts of monitoring the EU bioeconomy and single country bioeconomies. The European Commission provides its monitoring results for the EU bioeconomy and single MS online at https: / / ec.europa.eu/knowledge4policy/bioeconomy/monitoring en [90]. Several countries (Argentina, Australia, Germany, Malaysia, the Netherlands, South Africa, and the United States) are measuring the contribution of the bioeconomy to their overall economy or country objectives [91]. Germany is working on a comprehensive approach to monitor the bioeconomy by a joint inter-ministerial undertaking with three research projects. In the Netherlands, a bio-based economy monitor protocol to quantify the size and monitor its development was established already in 2013 [92]. However, so far there is, except for the efforts by the EC, no common and holistic approach to monitor and measure the bioeconomy across EU states and, therefore, it is not possible to compare the results between countries [91,93]. Furthermore, the majority of countries measure their bioeconomy not comprehensively using only economic indicators [91].

To monitor physical investments, they need to be differentiated by the kind and amount of biomass used, the production capacity as well as the bio-based products produced, and their intended use. For the products produced, prices and quantity are of importance as well as their destination: are they further processed within the region, processed outside the region but within the country, within the EU, or exported outside the EU, and what are countries of destination? To assess the future potential of the bioeconomy not only the investments into physical capital and related non-physical capital are important but also in research and development. In addition to the amount of private and public capital spent, another important aspect is to measure the impact and success of such kinds of investments with patent applications being an important indicator in this respect. The Organisation for Economic Co-operation and Development (OECD) patent data can be used as a source to identify the number of patents filed over time and space in the EU differentiated by the different sectors of the bioeconomy. Again, the sectors identified in Section 3.3 provide guidance for the classification of patent applications.

For monitoring the bioeconomy, a sectorial perspective is a very useful approach. One reason is that usually data are collected on an annual basis at the sectoral level, so that creates a good base for monitoring, measuring, and benchmarking. This has been followed by a number of previous projects $[84,86]$. For example, Ronzon et al. provide valuable information on economic indicators such as value added [86], but a more regional disaggregation, as well as disaggregation by products, has been expressed as a need by stakeholders [94].

\subsection{Indicators}

To monitor and measure the development of the bioeconomy, a set of indicators is essential. An indicator is a quantitative or qualitative measure, which must be measurable, comparable, replicable, and responsive to fluctuations in the development. They can help policymakers and other stakeholders to understand and interpret results, reveal trade-offs between policy measures, and formulate clear targets for their policies. There are several bioeconomy monitoring-related initiatives $[12,95]$ that proposed a set of indicators and other organizations are already collecting data for their indicators (e.g., by EUROSTAT, Forest Europe, European Environment Agency). EUROSTAT has 100 indicators related to the SDGs and ten indicators for the circular economy and in particular on biomass flows [96]. The ten indicators for the circular economy are part of a monitoring framework on the circular economy, which entails four thematic areas (i.e., production and consumption, waste management, secondary raw materials, competitiveness, and innovation). SDG indicators are important as some of them measure the bioeconomies contribution to sustainable development. This is supported by Ronzon and Sanjuan, who found that the 2018 EU Bioeconomy Strategy Update could contribute to 53 targets in 12 of the 17 SDGs by semantically mapping the action plan of the strategy with SDGs [97]. 
When defining our set of indicators, we considered a number of criteria. First, we focus on the bio-based industry and, therefore, gave preference to indicators for which a plausible link with bio-based production could be assumed (i.e., there should be a measurable effect). For instance, when looking at 'Greenhouse gas emissions', we are interested in the carbon removal capacity of forestry and emission reductions by agriculture and the bio-based industry. Second, we strive to have a balance of Main Indicators across the societal objectives from the 2018 Bioeconomy Strategy. Third, we aim at addressing all three dimensions of sustainability (i.e., environmental, social, and economic) as much as possible, although our focus is on the economic dimension of sustainability in particular. Especially the economic sustainability of the bioeconomy at the product level is neglected thus far [98]. Fourth, we include indicators that are considered important now (e.g., employment), as well as indicators that might become important in the future (e.g., education and investment) $[99,100]$. Table 2 presents the selected main and sub-indicators for our measuring and monitoring framework.

Table 2. Proposed list of indicators by societal objective for our framework.

\begin{tabular}{|c|c|c|c|}
\hline Main Indicator & Rationale & $\begin{array}{l}\text { Sustainability } \\
\text { Dimension }\end{array}$ & Source \\
\hline \multicolumn{4}{|c|}{ 1. Food and nutrition security } \\
\hline $\begin{array}{l}\text { Availability of food } \\
\text { Access to food } \\
\text { Utilization } \\
\text { Stability }\end{array}$ & $\begin{array}{l}\text { To assess the contribution of the bioeconomy to } \\
\text { food and nutrion security based on the widely } \\
\text { accepted four dimension of food security }\end{array}$ & Society & FAO [101] \\
\hline \multicolumn{4}{|c|}{ 2. Sustainable natural resource management } \\
\hline $\begin{array}{l}\text { Sustainability threshold levels } \\
\text { for Bioeconomy Technologies }\end{array}$ & $\begin{array}{l}\text { New indicator based on genuine investment } \\
\text { theory with a focus on the bio-based economy }\end{array}$ & Environment & $\begin{array}{l}\text { Own elaboration, } \\
\text { Bartolini et al. [102], } \\
\text { Wesseler et al. [103] }\end{array}$ \\
\hline Biodiversity & $\begin{array}{l}\text { Indispensable to assess the impact of biomass } \\
\text { production at the genetic, species, and } \\
\text { ecosystem level }\end{array}$ & Environment & $\begin{array}{c}\text { SAT-BBE [12], Bartolini } \\
\text { et al. [102], Plieninger } \\
\text { et al. [104], Strohbach } \\
\text { et al. [105], Weikard } \\
\text { et al. [106] }\end{array}$ \\
\hline Land cover & To assess land use conflicts & Environment & Lier et al. [88] \\
\hline Primary Biomass production & To assess biomass availability & Economy & BERST [95] \\
\hline Sustainable resource use & $\begin{array}{l}\text { To assess the sustainability of biomass } \\
\text { production }\end{array}$ & Environment & Lier et al. [88] \\
\hline \multicolumn{4}{|c|}{ 3. Dependence on non-renewable resources } \\
\hline $\begin{array}{l}\text { Bio-energy replacing } \\
\text { non-renewable energy }\end{array}$ & $\begin{array}{l}\text { To assess the direct substitutability of fossil } \\
\text { resources with biological resources }\end{array}$ & Environment & Own elaboration \\
\hline $\begin{array}{l}\text { Bio-material replacing } \\
\text { non-renewable resources }\end{array}$ & $\begin{array}{l}\text { To assess the direct substitutability of fossil } \\
\text { resources with biological resources }\end{array}$ & Environment & Lier et al. [88] \\
\hline Biomass self-sufficiency rate & To assess independence from biomass imports. & Economy & Own elaboration \\
\hline Material use efficiency & To assess the degree of circularity & Economy & Lier et al. [88] \\
\hline Certified bio-based products & $\begin{array}{l}\text { To assess the variety of products from } \\
\text { bio-based production. }\end{array}$ & Environment & Own elaboration \\
\hline \multicolumn{4}{|c|}{ 4. Mitigating and adapting to climate change } \\
\hline Greenhouse gas emissions & $\begin{array}{l}\text { Traditional indicator applied to bioeconomy } \\
\text { sectors }\end{array}$ & Environment & EUROSTAT [96] \\
\hline Climate footprint & $\begin{array}{l}\text { To assess } \mathrm{CO}_{2} \text { emissions for sectors based on } \\
\text { life cycle assessments of bio-based production }\end{array}$ & Environment & Own elaboration \\
\hline
\end{tabular}


Table 2. Cont.

\begin{tabular}{|c|c|c|c|}
\hline Main Indicator & Rationale & $\begin{array}{l}\text { Sustainability } \\
\text { Dimension }\end{array}$ & Source \\
\hline Climate change adaptation & $\begin{array}{l}\text { More indicators of adaption to climate change } \\
\text { impacts are needed. }\end{array}$ & Environment & Own elaboration \\
\hline \multicolumn{4}{|c|}{ 5. Employment and economic competitiveness } \\
\hline Innovation & $\begin{array}{l}\text { Traditional indicator applied in more sectorial } \\
\text { and spatial detail }\end{array}$ & Economy & $\begin{array}{l}\text { Lier et al. [88]; } \\
\text { SAT-BBE [12]; Own } \\
\text { elaboration }\end{array}$ \\
\hline Investments & $\begin{array}{l}\text { To assess biomass flows within the EU between } \\
\text { the rest of the world }\end{array}$ & Economy & $\begin{array}{l}\text { Lier et al. [88] Bartolini } \\
\text { et al. [102] }\end{array}$ \\
\hline $\begin{array}{l}\text { Value Added of the } \\
\text { bioeconomy sectors }\end{array}$ & $\begin{array}{l}\text { To assess product uptake of bio-based } \\
\text { production }\end{array}$ & Economy & Lier et al. [88] \\
\hline Comparative advantage & $\begin{array}{l}\text { To assess biomass flows within the EU between } \\
\text { the rest of the world }\end{array}$ & Economy & Own elaboration \\
\hline $\begin{array}{l}\text { Production and consumption } \\
\text { of non-food and feed } \\
\text { bio-based products }\end{array}$ & $\begin{array}{c}\text { Traditional indicator applied in more sectorial } \\
\text { and spatial detail }\end{array}$ & Economy & Own elaboration \\
\hline $\begin{array}{l}\text { Import and export of } \\
\text { bioeconomy raw materials } \\
\text { and products }\end{array}$ & $\begin{array}{l}\text { To assess biomass flows within the EU between } \\
\text { the rest of the world }\end{array}$ & Economy & Own elaboration \\
\hline Employment & $\begin{array}{l}\text { Traditional indicator applied in more sectorial } \\
\text { and spatial detail }\end{array}$ & Society & Lier et al. [88] \\
\hline Bioeconomy-driving Policies & $\begin{array}{c}\text { To assess policies, strategies, and legislation on } \\
\text { the bioeconomy }\end{array}$ & Society & Own elaboration \\
\hline
\end{tabular}

We assign the indicators to the five societal objectives based on the EC's 2018 Bioeconomy Strategy and distinguish between Main Indicators and Sub-Indicators. Based on consultation with stakeholders (in October 2018), we restrict the number of Main Indicators to 25 to provide a condensed view on, respectively, the transition of the bioeconomy, and on the realized (ex-post) and potential (ex-ante) effects of the EU bioeconomy. The Main Indicators can be disaggregated to Sub-Indicators, which offer a more detailed view. Our selection of indicators is based on stakeholder feedback and examination of the literature. As a starting point, we rely on indicators identified by Lier et al., who proposed indicators for assessing and monitoring the progress of a bioeconomy at the national level using a survey among ministries and research organizations responsible for national bioeconomy strategies, policies, and/or related initiatives [88]. We elaborated this set by evaluating the indicators that are used in the literature and monitoring projects to measure the five themes from the societal objectives. Based on the four before-mentioned criteria, we created a comprehensive framework of indicators, which considers social, environmental, and economic impacts.

A significant aspect of measuring the potential of sustainable bioeconomy is to consider indicators for innovation, supporting policies, strategies, and legislation. Policy measures can be implemented at a regional, national, supranational, or global level. These can make a significant contribution to promote the bioeconomy and often provide the foundation for establishing new bio-based industries. We suggest new spatially differentiated indicators for revealing these effects, measuring inter alia, 'Innovation' via 'Number of patents submitted by field and sub-field' and 'Innovation hurdle for different industries', and 'Policies' via 'Policy-induced investment hurdles' and 'Country level strategies'. As previously stated, it is desirable to measure the degree of circularity of the bioeconomy as well as its contribution to the Sustainable Development Goals. We use indicator measures, among others, 'Material use efficiency' and 'Sustainable resource use'. By measuring 'Bio-energy replacing non-renewable energy' and 'Bio-material replacing non-renewable 
resources ', we assess whether the bioeconomy reduces emissions compared to fossil-based, emission-intensive products. This can be done using bioeconomy transition indicators to quantify the substitution of fossil resources [107].

Bracco et al. stress the need for trade-related indicators to link national and global sustainability performances and ensure sustainable production of imported biomass [98]. We try to fill this gap by taking into account 'Import and export of bioeconomy raw materials and products' and 'Comparative Advantage' of countries for biomass production, which is not only relevant for environmental sustainability but also for biomass availability.

Several authors highlight the importance of environmental indicators for monitoring the sustainability of the bioeconomy [102,104,105]. We address this by including the availability of biomass and biological diversity used for producing the biomass by employing the index proposed by Weikard et al. [106]. Their index consists of the number of different sources of biomass and the abundance as well, which can be presented using different kinds of metrics such as at regional or national level as well as a share in land use and more. An important sub-indicator will be related to ecosystem resilience. This can be measured by changes in the maximum incremental social tolerable irreversible costs (MISTICSs) [103]. Habitats, landscape elements, and regulatory services are further important sub-indicators. They will be included by differentiating the different forms of land use as commonly done.

The methodologies and indicators described in this paper will contribute to the development of the EU Bioeconomy Monitoring system [90].

\subsection{Regulatory Challenges}

One of the important factors for the success of the EU Bioeconomy Strategy is the regulatory environment. Many of the new technologies for circular bioeconomy use methods based on new developments in the biological sciences such as CRISPR-Cas. The use of these technologies is heavily regulated and, in particular, application in plant breeding has become difficult under the current regulatory environment [43]. In some areas, recent improvements have been observed such as for the approval of microbial biological control agents [108] or novel foods [109]. Still, at the international level, approval for new products of importance for the circular bioeconomy in the EU is more time consuming [110] and hence much more expensive [111] and reforms are urgently needed [112]. Monitoring progress on regulatory issues will be important. They can be measured by identifying investment hurdles and how they change over time [20], the impacts of policies on those hurdles [113], and because of their importance for the success of the bioeconomy need to have priority. The measurement of the investment hurdles provides a quantitative measure, but qualitative measures such as changes in policies are important as well as they indirectly affect the sectorial growth [114].

\section{Conclusions}

This paper shows the bioeconomy receives wide support within the EU and beyond. Most stakeholders apply a sectorial view, defining the bioeconomy according to the sectors to be included and excluded. We developed a conceptual analysis framework for quantifying and analyzing the development of the bioeconomy, determined the general scope for the framework, and derived a set of indicators. Using the European Commission's definition as a basis for monitoring and measuring the bioeconomy framework, a wide range of sectors are part of the bioeconomy, including biomass producing activities, conventional biomass processing activities, novel biomass processing activities, and service-related activities that use biomass [5]. However, we emphasize the need for improvements in the methodologies for monitoring and measuring bio-based production. In the corresponding sub-sectors of the bioeconomy, existing data collecting methodologies and available data sets are lacking the most. A major issue is that national statistical agencies seldom distinguish between bio-based and non-bio-based products [115]. Furthermore, we expect at least some of these sectors to undergo a rapid and volatile development driven by technological change. A good monitoring system can support public policymakers to assess and steer these devel- 
opments and for industrial stakeholders to manage their investment plans. This requires that statistical offices in the EU collect data differentiated by product at member state and regional level. This may allow to provide a more detailed picture of the contribution of the circular bioeconomy toward regional growth [52].

The inclusion of innovation, policies, strategies, and legislation in the monitoring and measuring framework is important because these influence the development of the bioeconomy. Policy measures can be implemented at the regional, national, supranational, or global level. They can make an important contribution to the promotion of the bioeconomy and provide the foundation for establishing new bio-based industries. New indicators have been suggested for monitoring innovation, policies, strategies, and legislation. The indicators measure the changes over time. The indicators can be combined into time-series datasets and put onto a standardized scale that allows further transformation to compare developments among EU member states or even beyond as commonly done in the literature on economic growth [116] or trade [117].

It is widely considered crucial for society to achieve sustainable development on national, EU, and global levels, and the bioeconomy has an important role in that achievement. The sustainability of the bioeconomy is mostly attached to its environmental dimension, especially when it comes to sustainable production and use of biomass. To ensure that biomass is used sustainably, the bioeconomy needs to include strategies from the circular economy. A prominent example of this is the recycling of bio-based products. Our proposed set of indicators is designed to be able to measure the degree of circularity of the bioeconomy as well as its contribution to the Sustainable Development Goals.

However, many new bio-based products can be expected to enter the market, but not all can be explicitly singled out in statistics. First of all, procedures to collect new data for new products need to be adjusted, which is a long and expensive process. Secondly, the market of new bio-based products is still very volatile in the sense that many new initiatives appear and disappear from the market. Therefore, a selection needs to be made, which should be based on sound market analysis. A monitoring framework relies on data that is collected regularly and in a detailed manner.

Author Contributions: Conceptualization, M.K., M.v.L., P.J.V., and J.H.H.W.; formal analysis, M.K.; writing-original draft, M.K., M.v.L., P.J.V., and J.H.H.W.; writing-review and editing, K.C., O.C., R.D., W.H., M.L., M.v.L., R.M., H.v.M., S.P., T.R., J.S., D.V., P.J.V., M.V., J.H.H.W., and B.X.Z. All authors have read and agreed to the published version of the manuscript.

Funding: This contribution has received funding from the European Union's Horizon 2020 research and innovation program under grant agreement $N^{\circ} 773297$, the BioMonitor project (http: / / biomonitor.eu).

Institutional Review Board Statement: Not applicable.

Informed Consent Statement: Not applicable.

Data Availability Statement: No new data were created or analyzed in this study. Data sharing is not applicable to this article.

Conflicts of Interest: The authors declare no conflict of interest.

\section{References}

1. Wesseler, J.; von Braun, J. Measuring the Bioeconomy: Economics and Policies. Annu. Rev. Resour. Econ. 2017, 9, 275-298. [CrossRef]

2. European Commission. Communication from the Commission to the European Parliament, the European Council, the Council, the European Economic and Social Committee and the Committee of the Regions, The European Green Deal, COM/2019/640 final. 2019. Available online: https:/ / eur-lex.europa.eu/legal-content/EN/TXT/?uri=CELEX\%3A52019DC0640 (accessed on 4 January 2021).

3. Dietz, T.; Börner, J.; Förster, J.J.; von Braun, J. Governance of the bioeconomy: A global comparative study of national bioeconomy strategies. Sustainablility 2018, 10, 3190. [CrossRef]

4. Ministry of Economic Affairs and Climate Policy. The Position of the Bioeconomy in the Netherlands; Ministry of Economic Affairs and Climate Policy: The Hague, The Netherlands, 2018; pp. 1-8. 
5. European Commission. A Sustainable Bioeconomy for Europe: Strengthening the Connection between Economy, Society and the Environment. Updated Bioeconomy Strategy. 2018. ISBN 9789279941450. Available online: https://eur-lex.europa.eu/legalcontent/EN/TXT/?uri=CELEX\%3A52018DC0673 (accessed on 4 January 2021).

6. Knudsen, M.T.; Hermansen, J.E.; Thostrup, L.B. Mapping Sustainability Criteria for the Bioeconomy. 2015. Available online: https://www.scar-swg-sbgb.eu/lw_resource/datapool/_items/item_25/mapping_final_20_10_2015.pdf (accessed on 4 January 2021).

7. Griggs, D. The Sustainable Development Goals. In Companion to Environmental Studies; Routledge: Abington, UK, 2018; pp. 725-731.

8. D'Adamo, I.; Falcone, P.M.; Morone, P. A New Socio-economic Indicator to Measure the Performance of Bioeconomy Sectors in Europe. Ecol. Econ. 2020, 176, 106724. [CrossRef]

9. O'Brien, M.; Wechsler, D.; Bringezu, S.; Schaldach, R. Toward a systemic monitoring of the European bioeconomy: Gaps, needs and the integration of sustainability indicators and targets for global land use. Land Use Policy 2017, 66, 162-171. [CrossRef]

10. Vivien, F.D.; Nieddu, M.; Befort, N.; Debref, R.; Giampietro, M. The Hijacking of the Bioeconomy. Ecol. Econ. 2019, 159, 189-197. [CrossRef]

11. Sheppard, A.W.; Gillespie, I.; Hirsch, M.; Begley, C. Biosecurity and sustainability within the growing global bioeconomy. Curr. Opin. Environ. Sustain. 2011, 3, 4-10. [CrossRef]

12. SAT-BBE. Systems Analysis Description of the Bioeconomy; SAT-BBE: Wageningen, The Netherlands, 2018; pp. 1-40.

13. Tramper, J.; Zhu, Y. Modern Biotechnology: Panacea or New Pandora's Box? Wageningen Academic Pubishers: Wageningen, The Netherlands, 2012; Volume 49, ISBN 9789086867257.

14. Leopoldina, D.F.G. Wege zu Einer Wissenschaftlich Begründeten, Differenzierten Regulierung Genomeditierter Pflanzen in der EU; National Academy of Sciences Leopoldina, Union of German Academies of Sciences and the German Research Foundation: Halle, Germany, 2019.

15. Yoshida, T. (Ed.) Applied Bioengineering; Wiley-VCH Verlag GmbH \& Co. KGaA: Weinheim, Germany, 2017; ISBN 9783527800599.

16. Wesseler, J.; Zilberman, D. Biotechnology, bioeconomy, and sustainable life on land. In Transitioning to Sustainable Life on Land; Beckmann, V., Ed.; MDPI: Basel, Switzerland, 2021; in print.

17. Paarlberg, R. A dubious success: The NGO campaign against GMOs. GM Crops Food 2014, 5, 223-228. [CrossRef]

18. Smart, R.D.; Blum, M.; Wesseler, J. EU member states' voting for authorizing genetically engineered crops: A regulatory gridlock. Ger. J. Agric. Econ. 2015, 64, 244-262.

19. Smart, R.D.; Blum, M.; Wesseler, J. Trends in Approval Times for Genetically Engineered Crops in the United States and the European Union. J. Agric. Econ. 2017, 68, 182-198. [CrossRef]

20. Wesseler, J.; Smart, R.D.; Thomson, J.; Zilberman, D. Foregone benefits of important food crop improvements in Sub-Saharan Africa. PLoS ONE 2017, 12, e0181353. [CrossRef]

21. Venus, T.J.; Drabik, D.; Wesseler, J. The role of a German multi-stakeholder standard for livestock products derived from non-GMO feed. Food Policy 2018, 78, 58-67. [CrossRef]

22. Wesseler, J.; Politiek, H.; Zilberman, D. The Economics of Regulating New Plant Breeding Technologies-Implications for the Bioeconomy illustrated by a Survey Among Dutch Plant Breeders. Front. Plant. Sci. 2019, 10, 1597. [CrossRef] [PubMed]

23. Martin-Laffon, J.; Kuntz, M.; Ricroch, A.E. Worldwide CRISPR patent landscape shows strong geographical biases. Nat. Biotechnol. 2019, 37, 613-620. [CrossRef] [PubMed]

24. European Commission. The European Green Deal Investment Plan and JTM Explained. Available online: https:/ / ec.europa.eu/ commission/presscorner/detail/en/qanda_20_24 (accessed on 22 December 2020).

25. Watanabe, C.; Naveed, N.; Neittaanmäki, P. Digitalized bioeconomy: Planned obsolescence-driven circular economy enabled by Co-Evolutionary coupling. Technol. Soc. 2019, 56, 8-30. [CrossRef]

26. Walter, A.; Finger, R.; Huber, R.; Buchmann, N. Smart farming is key to developing sustainable agriculture. Proc. Natl. Acad. Sci. USA 2017, 114, 6148-6150. [CrossRef] [PubMed]

27. Antonucci, F.; Figorilli, S.; Costa, C.; Pallottino, F.; Raso, L.; Menesatti, P. A review on blockchain applications in the agri-food sector. J. Sci. Food Agric. 2019, 99, 6129-6138. [CrossRef]

28. Salerno, A. Dalla Piantagione Alla Tazzina: La Blockchain Entra nel Caffè-Blockchain 4innovation. Available online: https: / / www.blockchain4innovation.it/mercati/agrifood/dalla-piantagione-alla-tazzina-la-blockchain-entra-nel-caffe/ (accessed on 29 November 2019).

29. Provenance from Shore to Plate: Tracking Tuna on the Blockchain I Provenance. Available online: https://www.provenance.org/ tracking-tuna-on-the-blockchain\#overview (accessed on 29 November 2019).

30. Dongo, D. Blockchain Nella Filiera Alimentare, il Prototipo di Bari I GIFT. Available online: https:/ / www.greatitalianfoodtrade. it/consum-attori/blockchain-nella-filiera-alimentare-il-prototipo-di-bari (accessed on 29 November 2019).

31. Näyhä, A.; Hetemäki, L.; Stern, T. New products outlook. In Future of the European Forest-Based Sector: Structural Changes Towards Bioeconomy. What Science Can Tell Us; European Forest Institute: Joensuu, Finland, 2014; pp. 43-52.

32. Tollefson, J. The wooden skyscrapers that could help to cool the planet. Nature 2017, 545, 280-282. [CrossRef]

33. Hurmekoski, E.; Jonsson, R.; Korhonen, J.; Jänis, J.; Mäkinen, M.; Leskinen, P.; Hetemäki, L. Diversification of the forest industries: Role of new wood-based products. Can. J. For. Res. 2018, 48, 1417-1432. [CrossRef] 
34. UN. Forest Products Annual Market. Review 2017-2018; Geneva Timber and Forest Study Papers; UN: New York, NY, USA, 2019; ISBN 9789210473507.

35. Investopedia. Horizontal Integration. Available online: https://www.investopedia.com/terms/h/horizontalintegration.asp (accessed on 17 December 2020).

36. Cherubini, F. The biorefinery concept: Using biomass instead of oil for producing energy and chemicals. Energy Convers. Manag. 2010, 51, 1412-1421. [CrossRef]

37. BNetzA Marktstammdatenregister. Auswertung des Registers durch das ZSW Baden-Württemberg. Available online: https: //www.bundesnetzagentur.de/DE/Sachgebiete/ElektrizitaetundGas/Unternehmen_Institutionen/ErneuerbareEnergien/ ZahlenDatenInformationen/EEG_Registerdaten/EEG_Registerdaten_node.html;jsessionid=F68354DE8042158224AE13C9BC0 4E00C (accessed on 15 September 2019).

38. Parisi, C. Research Brief: Biorefineries distribution in the EU. Eur. Comm. Jt. Res. Cent. 2018, 1-8. [CrossRef]

39. Clomburg, J.M.; Crumbley, A.M.; Gonzalez, R. Industrial biomanufacturing: The future of chemical production. Science 2017, 355, aag0804. [CrossRef] [PubMed]

40. Choi, H.S.; Grethe, H.; Entenmann, S.K.; Wiesmeth, M.; Blesl, M.; Wagner, M. Potential trade-offs of employing perennial biomass crops for the bioeconomy in the EU by 2050: Impacts on agricultural markets in the EU and the world. GCB Bioenergy 2019, 11, 483-504. [CrossRef]

41. Levin Institute What Is Globalization?/Globalization101. Available online: https://www.globalization101.org/what-isglobalization/ (accessed on 6 December 2019).

42. Hetemäki, L.; Hurmekoski, E. Forest products market outlook. In Future of the European Forest-Based Sector: Structural Changes Towards Bioeconomy. What Science Can Tell Us; European Forest Institute: Joensuu, Finland, 2014; pp. 15-32.

43. Purnhagen, K.; Wesseler, J. EU Regulation of New Plant Breeding Technologies and Their Possible Economic Implications for the EU and Beyond. Appl. Econ. Perspect. Policy 2020. [CrossRef]

44. Lindner, M.; Maroschek, M.; Netherer, S.; Kremer, A.; Barbati, A.; Garcia-Gonzalo, J.; Seidl, R.; Delzon, S.; Corona, P.; Kolström, M.; et al. Climate change impacts, adaptive capacity, and vulnerability of European forest ecosystems. For. Ecol. Manag. 2010, 259, 698-709. [CrossRef]

45. Challinor, A.J.; Adger, W.N.; Benton, T.G. Climate risks across borders and scales. Nat. Clim. Chang. 2017, 7, 621-623. [CrossRef]

46. Verkerk, P.J.; Martinez de Arano, I.; Palahí, M. The bio-economy as an opportunity to tackle wildfires in Mediterranean forest ecosystems. For. Policy Econ. 2018, 86, 1-3. [CrossRef]

47. Spierling, S.; Knüpffer, E.; Behnsen, H.; Mudersbach, M.; Krieg, H.; Springer, S.; Albrecht, S.; Herrmann, C.; Endres, H.J. Bio-based plastics-A review of environmental, social and economic impact assessments. J. Clean. Prod. 2018, 185, 476-491. [CrossRef]

48. Leskinen, P.; Cardellini, G.; González-García, S.; Hurmekoski, E.; Sathre, R.; Seppälä, J.; Smyth, C.; Stern, T.; Verkerk, P.J. Substitution Effects of Wood-Based Products in Climate Change Mitigation, From Science to Policy 7. 2018. Available online: https:/ / efi.int/sites/default/files/files/publication-bank/2019/efi_fstp_7_2018.pdf (accessed on 4 January 2021).

49. Spencer, W.F.; Cliath, M.M.; van den Oever, M.; Molenveld, K.; van der Zee, M.; Bos, H. Bio-Based and Biodegradable Plastics: Facts and Figures: Focus on Food Packaging in the Netherlands; Wageningen Food \& Biobased Research: Wageningen, The Netherlands, 2017; ISBN 9789463431217.

50. Issa, I.; Delbrück, S.; Hamm, U. Bioeconomy from experts' perspectives-Results of a global expert survey. PLoS ONE 2019, 14, e0215917. [CrossRef]

51. Van Berkel, J.; Delahaye, R. Material Flow Monitor 2016-Technical Report Index; CBS Den Haag: The Hague, The Netherlands, 2019.

52. D'Adamo, I.; Falcone, P.M.; Imbert, E.; Morone, P. Exploring regional transitions to the bioeconomy using a socio-economic indicator: The case of Italy. Econ. Polit. 2020, 1-33. [CrossRef]

53. Capasso, M.; Klitkou, A. Socioeconomic indicators to monitor Norway's bioeconomy in transition. Sustainablitily 2020, $12,3173$. [CrossRef]

54. Bringezu, S.; Schütz, H.; Arnold, K.; Merten, F.; Kabasci, S.; Borelbach, P.; Michels, C.; Reinhardt, G.A.; Rettenmaier, N. Global implications of biomass and biofuel use in Germany-Recent trends and future scenarios for domestic and foreign agricultural land use and resulting GHG emissions. J. Clean. Prod. 2009, 17. [CrossRef]

55. Von Braun, J. Bioeconomy-The global trend and its implications for sustainability and food security. Glob. Food Sec. 2018, 19, 81-83. [CrossRef]

56. Dolgopolova, I.; Teuber, R. Consumers' Willingness-to-pay for Health-enhancing Attributes in Food Products: A Meta-analysis 2016. [CrossRef]

57. Reinders, M.J.; Onwezen, M.C.; Meeusen, M.J.G. Can bio-based attributes upgrade a brand? How partial and full use of bio-based materials affects the purchase intention of brands. J. Clean. Prod. 2017, 162, 1169-1179. [CrossRef]

58. Sijtsema, S.J.; Onwezen, M.C.; Reinders, M.J.; Dagevos, H.; Partanen, A.; Meeusen, M. Consumer perception of bio-based products-An exploratory study in 5 European countries. NJAS-Wagening. J. Life Sci. 2016, 77, 61-69. [CrossRef]

59. Keegan, D.; Kretschmer, B.; Elbersen, B.; Panoutsou, C. Cascading use: A systematic approach to biomass beyond the energy sector. Biofuels Bioprod. Biorefining 2013, 7, 193-206. [CrossRef]

60. Nitescu, D.C.; Murgu, V. The Bioeconomy and Foreign Trade in Food Products-A Sustainable Partnership at the European Level? Sustainability 2020, 12, 2460. [CrossRef] 
61. SAT-BBE. Evaluation of Expected Impacts and Monitoring the Trajectory of the Bioeconomy; SAT-BBE: Wageningen, The Netherlands, 2015; pp. 1-51.

62. Tsiropoulos, I.; Hoefnagels, R.; van den Broek, M.; Patel, M.K.; Faaij, A.P.C. The role of bioenergy and biochemicals in $\mathrm{CO}_{2}$ mitigation through the energy system-a scenario analysis for the Netherlands. GCB Bioenergy 2017, 9, 1489-1509. [CrossRef]

63. European Commission. Closing the Loop-An EU Action Plan for the Circular Economy; Communication From the Commission to the European Parliament, the Council, the European Economic and Social Committee and the Committee of the Regions; European Commission: Brussels, Belgium, 2015.

64. European Commission. Communication from the Commission to the European Parliament, the Council, the European Economic and Social Committee and the Committee of the Regions A New Circular Economy Action Plan. For. A Cleaner and More Competitive Europe; European Commission: Brussels, Belgium, 2020.

65. Van Leeuwen, M. Final Report of BERST Project. 2016. Available online: https://cordis.europa.eu/project/id/613671/reporting (accessed on 24 June 2016).

66. Ronzon, T.; Lusser, M.; Klinkenberg, M.; Landa, L.; Sanchez Lopez, J.; M’Barek, R.; Hadjamu, G.; Belward, A.; Giuntoli, J.; Cristobal, J.; et al. Joint Research Centre Science for Policy Report: Bioeconomy Report 2016; Joint Research Centre: Brussels, Belgium, 2016.

67. Bugge, M.M.; Hansen, T.; Klitkou, A. What is the bioeconomy? A review of the literature. Sustainablitily 2016, 8, 691. [CrossRef]

68. BIOÖKONOMIERAT. Global Bioeconomy Summit Communiqué Global Bioeconomy Summit 2018 Innovation in the Global Bioeconomy for Sustainable and Inclusive Transformation and Wellbeing. 2018. Available online: https://gbs2018.com/ fileadmin/gbs2018/GBS_2018_Report_web.pdf (accessed on 4 January 2021).

69. European Bioeconomy. Alliance Bioeconomy-A Motor for the Circular Economy; European Commission: Brussels, Belgium, 2016.

70. Confederation of European Forest Owners. Private Forest Owners Call for An Ambitious Update of the EU Bioeconomy Strategy; Confederation of European Forest Owners: Brussels, Belgium, 2017.

71. D'Amato, D.; Droste, N.; Allen, B.; Kettunen, M.; Lähtinen, K.; Korhonen, J.; Leskinen, P.; Matthies, B.D.; Toppinen, A. Green, circular, bio economy: A comparative analysis of sustainability avenues. J. Clean. Prod. 2017, 168, 716-734. [CrossRef]

72. Unep; ILO; UNIDO; UNDP; Unitar. Advancing an Inclusive Green Economy: Rationale and Context-Definitions for Green Economy. 2012. Available online: https://unitar.org/sites/default/files/uploads/egp/Section1/PDFs/1.3\%20Definitions\%20 for\%20Green\%20Economy.pdf (accessed on 4 January 2021).

73. Pülzl, H.; Kleinschmit, D.; Arts, B. Bioeconomy-an emerging meta-discourse affecting forest discourses? Scand. J. For. Res. 2014, 29, 386-393. [CrossRef]

74. Dubois, O.; Gomez San Juan, M. How Sustainability is Addressed in Official Bioeconomy Strategies at International, National and Regional Levels: An Overview. 2016. Available online: http:/ /www.fao.org/3/a-i5998e.pdf (accessed on 4 January 2021).

75. Carus, M.; Dammer, L. The Circular Bioeconomy-Concepts, Opportunities, and Limitations. Ind. Biotechnol. $2018,14,83-91$. [CrossRef]

76. European Commission. Expert Group Report-Review of the EU Bioeconomy Strategy and its Action Plan; European Commission: Brussels, Belgium, 2017.

77. Buongiorno, J. On the accuracy of international forest product statistics. For. An. Int. J. For. Res. 2018, 91, 541-551. [CrossRef]

78. Ellen MacArthur Foundation. Towards the Circular Economy-Economic and Business Rationale for An Accelerated Transition. 2013. Available online: https:/ / www.ellenmacarthurfoundation.org/assets/downloads/publications/Ellen-MacArthurFoundation-Towards-the-Circular-Economy-vol.1.pdf (accessed on 4 January 2021).

79. EuropaBio. Strengthening Biotechnology and the Eu Project; EuropaBio: Brussels, Belgium, 2017.

80. Hetemäki, L.; Hanewinkel, M.; Muys, B.; Ollikainen, M.; Palahí, M.; Trasobares, A. Leading the Way to a European Circular Bioeconomy Strategy; European Forest Institute: Joensuu, Finland, 2017; Volume 5, p. 52.

81. European Commission. A Clean Planet for all-A European long-term strategic vision for a prosperous, modern, competitive and climate neutral economy. Depth Anal. Support Comm. Commun. Com 2018, 773, 114.

82. Heijman, W. How big is the bio-business? Notes on measuring the size of the Dutch bio-economy. NJAS-Wagening. J. Life Sci. 2016, 77, 5-8. [CrossRef]

83. Kuosmanen, T.; Kuosmanen, N.; El-Meligli, A.; Ronzon, T.; Gurria, P.; Iost, S.; M’Barek, R. How Big is the Bioeconomy? Reflections from An Economic Perspective; EUR 30167 EN; Publications Office of the European Union: Luxembourg, 2020.

84. Efken, J.; Dirksmeyer, W.; Kreins, P.; Knecht, M. Measuring the importance of the bioeconomy in Germany: Concept and illustration. NJAS-Wagening. J. Life Sci. 2016, 77, 9-17. [CrossRef]

85. Ronzon, T.; Piotrowski, S.; M’Barek, R.; Carus, M. A systematic approach to understanding and quantifying the EU's bioeconomy. Bio-Based Appl. Econ. 2017, 6, 1-17. [CrossRef]

86. Ronzon, T.; Piotrowski, S.; M'barek, R.; Carus, M.; Tamošiūnas, S. Job and Wealth in the EU Bioeconomy. Available online: http:/ / data.europa.eu/89h/7d7d5481-2d02-4b36-8e79-697b04fa4278 (accessed on 4 January 2021).

87. Fumagalli, S.; Trenti, S. A First Attempt to Measure the Bio-Based Economy. 2014. Available online: https://group.intesasanpaolo. $\mathrm{com} /$ content/dam/portalgroup/repository-documenti/public/Contenuti/RISORSE/Documenti\%20PDF/en_sostenibilita/ CNT-05-000000023F746.pdf (accessed on 4 January 2021). 
88. Lier, M.; Aarne, M.; Kärkkäinen, L.; Korhonen, K.T.; Yli-Viikari, A.; Packalen, T. Synthesis on Bioeconomy Monitoring Systems in the EU Member States-Indicators for Monitoring the Progress of Bioeconomy; Natural Resources Institute Finland (Luke): Helsinki, Finland, 2018.

89. Piotrowski, S.; Carus, M.; Carrez, D. European Bioeconomy in Figures. Available online: www.biconsortium.eu (accessed on 4 January 2021).

90. Robert, N.; Giuntoli, J.; Araujo, R.; Avraamides, M.; Balzi, E.; Barredo, J.I.; Baruth, B.; Becker, W.; Borzacchiello, M.T.; Bulgheroni, C.; et al. Development of a bioeconomy monitoring framework for the European Union: An integrative and collaborative approach. New Biotechnol. 2020, 59, 10-19. [CrossRef] [PubMed]

91. Bracco, S.; Calicioglu, O.; Juan, M.G.S.; Flammini, A.; Gomez San Juan, M.; Flammini, A. Assessing the contribution of bioeconomy to the total economy: A review of national frameworks. Sustainablility 2018, 10, 1698. [CrossRef]

92. Meesters, K.P.H.; van Dam, J.E.G.; Bos, H.L. Protocol Monitoring Materiaalstromen Biobased Economie; Wageningen UR Food Biobased Res: Wageningen, The Netherlands, 2013.

93. Linser, S.; Lier, M. The contribution of sustainable development goals and forest-related indicators to national bioeconomy progress monitoring. Sustainablility 2020, 12, 2898. [CrossRef]

94. Piotrowski, S.; Wesseler, J.; Kardung, M.; Van Leeuwen, M.; Van Meijl, H.; Costenoble, O.; Vrins, M.; De Groot, T.; Jansen, K. First Stakeholder Workshop-D7.2. 2019. Available online: http://biomonitor.eu/wp-content/uploads/2019/01/D7.2_FirstStakeholder-Workshop.pdf (accessed on 4 January 2021).

95. BERST. Criteria and Indicators Describing the Regional Bioeconomy. 2014. Available online: https://www.wecr.wur.nl/ BerstPublications/D1.1\%20Criteria\%20and\%20Indicators\%20describing\%20Regional\%20Bioeconomy\%20(Oct\%202014).pdf (accessed on 4 January 2021).

96. Eurostat. Sustainable Development in the European Union-Monitoring Report on Progress Towards the SDGs in An EU Context-2019 Edition. 2019. ISBN 978-92-76-00777-7. Available online: https:/ / ec.europa.eu/eurostat/web/products-statisticalbooks / - KS-02-19-165 (accessed on 4 January 2021).

97. Ronzon, T.; Sanjuán, A.I. Friends or foes? A compatibility assessment of bioeconomy-related Sustainable Development Goals for European policy coherence. J. Clean. Prod. 2020, 254, 119832. [CrossRef] [PubMed]

98. Bracco, S.; Tani, A.; Çalıcıoğlu, Ö.; Gomez San Juan, M.; Bogdanski, A. Indicators to Monitor and Evaluate the Sustainability of Bioeconomy. Overview and A Proposed Way Forward; FAO Environment and Natural Resource Management Working Paper: Rome, Italy, 2019.

99. Philippidis, G.; Bartelings, H.; Smeets, E. Sailing into Unchartered Waters: Plotting a Course for EU Bio-Based Sectors. Ecol. Econ. 2018, 147, 410-421. [CrossRef]

100. Urmetzer, S.; Lask, J.; Vargas-Carpintero, R.; Pyka, A. Learning to change: Transformative knowledge for building a sustainable bioeconomy. Ecol. Econ. 2020, 167, 106435. [CrossRef]

101. FAO. Declaration of the World Summit on Food Security; WSFS: Wilmington, DE, USA, 2009.

102. Bartolini, F.; Gava, O.; Brunori, G. Biogas and EU's 2020 targets: Evidence from a regional case study in Italy. Energy Policy 2017, 109, 510-519. [CrossRef]

103. Wesseler, J.; Scatasta, S.; Nillesen, E. The Maximum Incremental Social Tolerable Irreversible Costs (MISTICs) and other benefits and costs of introducing transgenic maize in the EU-15. Pedobiologia 2007, 51, 261-269. [CrossRef]

104. Plieninger, T.; Torralba, M.; Hartel, T.; Fagerholm, N. Perceived ecosystem services synergies, trade-offs, and bundles in European high nature value farming landscapes. Landsc. Ecol. 2019, 34, 1565-1581. [CrossRef]

105. Strohbach, M.W.; Kohler, M.L.; Dauber, J.; Klimek, S. High Nature Value farming: From indication to conservation. Ecol. Indic. 2015, 57, 557-563. [CrossRef]

106. Weikard, H.-P.; Punt, M.; Wesseler, J. Diversity measurement combining relative abundances and taxonomic distinctiveness of species. Divers. Distrib. 2006, 12, 215-217. [CrossRef]

107. Jander, W.; Grundmann, P. Monitoring the transition towards a bioeconomy: A general framework and a specific indicator. J. Clean. Prod. 2019, 236, 117564. [CrossRef]

108. Frederiks, C.; Wesseler, J.H.H. A comparison of the EU and US regulatory frameworks for the active substance registration of microbial biological control agents. Pest. Manag. Sci. 2019, 75, 87-103. [CrossRef]

109. Zarbà, C.; Chinnici, G.; D'Amico, M. Novel Food: The Impact of Innovation on the Paths of the Traditional Food Chain. Sustainability 2020, 12, 555. [CrossRef]

110. Jin, Y.; Drabik, D.; Heerink, N.; Wesseler, J. Getting an Imported GM Crop Approved in China. Trends Biotechnol. 2019, 37, 566-569. [CrossRef] [PubMed]

111. Purnhagen, K.P.; Wesseler, J.H.H. Maximum vs minimum harmonization: What to expect from the institutional and legal battles in the EU on gene editing technologies. Pest. Manag. Sci. 2019, 75, 2310-2315. [CrossRef] [PubMed]

112. Eriksson, D.; Kershen, D.; Nepomuceno, A.; Pogson, B.J.; Prieto, H.; Purnhagen, K.; Smyth, S.; Wesseler, J.; Whelan, A. A comparison of the EU regulatory approach to directed mutagenesis with that of other jurisdictions, consequences for international trade and potential steps forward. New Phytol. 2019, 222, 1673-1684. [CrossRef] [PubMed]

113. Wesseler, J.; Zhao, J. Real Options and Environmental Policies: The Good, the Bad, and the Ugly. Annu. Rev. Resour. Econ. 2019, 11, 43-58. [CrossRef]

114. Acemoglu, D.; Azar, P.D. Endogenous Production Networks. Econometrica 2020, 88, 33-82. [CrossRef] 
115. Jander, W.; Wydra, S.; Wackerbauer, J.; Grundmann, P.; Piotrowski, S. Monitoring bioeconomy transitions with economicenvironmental and innovation indicators: Addressing data gaps in the short term. Sustainability 2020, 12, 4683. [CrossRef]

116. Quah, D.T. Empirics for economic growth and convergence. Eur. Econ. Rev. 1996, 40, 1353-1375. [CrossRef]

117. Zaghini, A. Evolution of trade patterns in the new EU member states. Econ. Transit. 2005, 13, 629-658. [CrossRef] 